University of Wollongong

Research Online

Faculty of Business - Papers (Archive)

Faculty of Business and Law

2013

Does CEO pay dispersion matter in an emerging market? Evidence from China's listed firms

Fang $\mathrm{Hu}$

Griffith University

Xiaofei Pan

University of Wollongong, xpan@uow.edu.au

Gary Tian

University of Wollongong, gtian@uow.edu.au

Follow this and additional works at: https://ro.uow.edu.au/buspapers

Part of the Business Commons

Research Online is the open access institutional repository for the University of Wollongong. For further information contact the UOW Library: research-pubs@uow.edu.au 


\title{
Does CEO pay dispersion matter in an emerging market? Evidence from China's listed firms
}

\begin{abstract}
This paper examines how the institutional features of emerging economies (i.e., government ownership, political connections, and market reform) influence CEO pay-dispersion incentives. Consistent with our expectation, we find that CEO pay dispersion generally provides a tournament incentive in China's emerging market, as it is positively associated with firm performance. In addition, tournament incentives are weaker where firms are controlled by the government and where the CEO is politically connected, but it became stronger after the China's split-share structure reforms. Further, we find that in state controlled firms the satisfaction gained by meeting multiple economic and social goals largely reduces the effectiveness of tournament incentives, while the managerial agency problems inherent in private firms might mitigate them.
\end{abstract}

\section{Keywords}

era2015

Disciplines

Business

\section{Publication Details}

Hu, F., Pan, X. \& Tian, G. (2013). Does CEO pay dispersion matter in an emerging market? Evidence from China's listed firms. Pacific-Basin Finance Journal, 24 235-255. 
Does CEO pay dispersion matter in an emerging market? Evidence from China's listed firms ${ }^{\#}$

Fang $\mathrm{Hu}^{\mathrm{a}}$, Xiaofei Pan $^{\mathrm{b}}$, Gary Tian ${ }^{\mathrm{c} *}$

${ }^{a}$ Griffith University, Australia

b, c University of Wollongong, Australia

\begin{abstract}
This paper examines how the institutional features of emerging economies (i.e., government ownership, political connections, and market reform) influence CEO pay-dispersion incentives. Consistent with our expectation, we find that CEO pay dispersion generally provides a tournament incentive in China's emerging market, as it is positively associated with firm performance. In addition, tournament incentives are weaker where firms are controlled by the government and where the CEO is politically connected, but it became stronger after the China's split-share structure reforms. Further, we find that in state controlled firms the satisfaction gained by meeting multiple economic and social goals largely reduces the effectiveness of tournament incentives, while the managerial agency problems inherent in private firms might mitigate them.
\end{abstract}

JEL Classifications: G32; G34

Key words: CEO pay dispersion, tournament incentive, political connections, split-share structure reform

\footnotetext{
\# We acknowledge the valuable suggestions and comments on this paper by Professor Jun-Koo Kang, editor of the PacificBasin Finance Journal, and the anonymous referee, as well as comments by participants of the seminar organized by Department of Accounting, Finance and Economics, Griffith University, October 12, 2012.

${ }^{*}$ Corresponding author at: School of Accounting and Finance, University of Wollongong, NSW 2522 Australia. Tel: +612 42214301 , Fax: +612 42214297.

Email address gtian@uow.edu.au (G. Tian)
} 


\section{Does CEO pay dispersion matter in an emerging market? Evidence from China's listed firms}

\section{Introduction}

Executive pay dispersion, defined as the pay differential between the CEO and other executives, has implications for the inner workings of the top executive team, and for overall firm performance (Bebchuk et al., 2011). While many studies examine the level and structure of executive compensation and its relationship with performance (Jensen and Murphy 1990; Yermack 1996; Core et al. 1999; Murphy 1999), controversy remains about how executive pay differentials arise and affect firm performance (Kale et al., 2009; Bebchuk et al., 2011; Chen et al., 2011a). Since the emergence of the global financial crisis, the media has been critical of the large gap in pay between CEOs and employees in most countries, and of the resulting severe agency problems and inequality. While many governments have tried to reduce the gap by restricting ever-higher CEO compensation ${ }^{1}$, public anger and resentment of it has not ceased.

The extant literature tends toward two views regarding the optimal (or appropriate) level of pay dispersion. The tournament viewpoint sees the pay differential in the corporate hierarchy as defining an arena where individuals compete for promotion and rewards. Highperforming executives with considerable managerial potential win promotion and commensurate compensation. A large spread of compensation across corporate hierarchical levels attracts talented and venturesome participants to compete in the managerial tournament by providing extra incentives to exert effort. This viewpoint supports the view that a large pay dispersion is necessary to provide appropriate incentives for executives to perform (Main et al., 1993; Eriksson, 1999; Kale et al., 2009). ${ }^{2}$ The entrenchment viewpoint sees the large pay gap between the CEO and other executives as giving an indication of CEO power (Lambert et al., 1993), since powerful CEOs are entrenched and find it easier to expropriate shareholder wealth. Empirical studies show that the excess executive-pay gap might reflect

\footnotetext{
${ }^{1}$ These governments include the U.S., Germany, the U.K., France, Sweden, China and some others. Specifically, the U.S. Department of the Treasury has announced a $\$ 500,000$ cap on top-paid executives for the most distressed financial institutions, and the German government places a $€ 500,000$ cap on top executives in banks in financial distress.

${ }^{2}$ Empirical evidence is mixed on the tournament viewpoint. For example, O'Reilly et al. (1988) do not find support for the tournament argument in a sample of 105 Fortune 500 firms, and Conyon et al. (2001) report that variation in executive compensation is not associated with enhanced firm performance in a sample of 100 UK firms in 1997.
} 
agency problems and reduce firm value and performance (Adams et al., 2005; Landier et al., 2008; Bebchuk et al., 2011).

Evidence from emerging markets such as China has only recently started to appear. Chen et al. (2011a) document that managerial powers are positively related to executive remuneration, and organizational levels and contestant numbers have positive effects on pay differences between executives. They provide preliminary evidence that the pay gap has a positive effect on firm performance, and that this effect is stronger in firms that are relatively less controlled by the government. Lin and Lu (2009) also find that the pay gap is positively related to firm performance, and that this relationship is more significant with higher managerial power (defined as larger managerial ownership and longer tenure of the CEO). Although the evidence for pay dispersion's positive effect on performance has been established, there is no comprehensive analysis showing how it affects firm performance and by what mechanism.

This paper extends the existing literature by examining the channels through which the institutional features of emerging markets shape executive pay dispersion, and how they affect tournament incentives in China's listed firms. Specifically, it identifies the institutional features that can affect pay dispersion and the relationship between pay dispersion and firm performance, including state ownership, CEO political connections and reform of the splitshare structure. Moreover, in contrast to Lin and Lu (2009), this paper follows Bebchuk et al. (2011) in treating managerial power as an entrenchment, and investigates its impact on the association between pay dispersion and firm performance.

The institutional background of China's listed firms encompasses several important features that shape executive pay dispersion, and which may differ from those in the U.S. and other countries. First, while CEO compensation has been increasingly important, and more related to firm's profits since China's economic reform of executive compensation (Groves et al., 1994; Kato and Long, 2005; Firth et al., 2006b; Zheng et al., 2008; Cao et al., 2011a), the executive pay dispersion remains constrained by the dominance of state ownership and government intervention. In addition to the goals of maximizing shareholders' value, the state owner (in other words, the government) also has non-economic goals of maintaining social 
equality and harmony. Due to these non-economic goals, the pay differential in the corporate hierarchy, especially in SOEs, would attract close political scrutiny because it is a potential point of conflict. Furthermore, the competition for completion of these non-economic goals does not necessarily lead to an improvement in performance (Jensen, 2001). Independent from the incentives provided by executive compensation, performance improvement in SOEs could be related to policy support obtained from the government. Secondly, an implicit incentive scheme such as perquisites, political promotion, chasing personal fame and other "grey" income on the position seems to be prevalent, but not directly observable, in China's emerging market (Chen et al., 2010b; Cao et al., 2011b). In such an economic environment, which lacks a functioning external labour market, the complexity of executive incentive casts doubts on the value of explicit monetary compensation. This study applies the notion of pay dispersion to such market conditions to understand executive incentive.

In accordance with previous research (Kale et al., 2009; Bebchuk et al., 2011), this study measured CEO pay dispersion by i) the pay gap between the CEO and other top executives (GAP), and ii) the ratio of CEO pay to the total compensation of the top five executives within the top management team (CPS). It shows that the mean pay gap is $250,868 \mathrm{RMB}$ (equivalent to $36,891 \mathrm{USD}$ ), which is much lower than the $778,000 \mathrm{USD}$ reported by Kale et al. (2009), and the ratio of CEO pay to the aggregate compensation of the top five executives across our sample in China is $31.9 \%$, which is around $3.9 \%$ lower than the figure found by Bebchuk et al., (2011) for U.S firms. Moreover, pay dispersion in privately controlled firms is $30.1 \%$ larger than in SOEs, and the CPS is $6.5 \%$ higher. In private firms where CEOs are politically connected, the pay gap is $20 \%$ higher and the CPS is $10 \%$ higher than in those where the CEOS do not have such connections.

Our empirical analysis find that pay dispersion is positively related to firm performance, which supports the tournament theory (Lazear and Rosen, 1981), and that the positive effect of CEO pay dispersion on firm performance is weaker in state-controlled firms and in firms where CEOs are politically connected. We further found in a subsample of SOEs that tournament incentives are weaker if firms seek for goals that are more political, such as the remittance of tax imposed by governments; in a subsample of private firms, tournament 
incentives become weaker if the CEO is also the owner who controls the firm. These findings suggest that the multiple goals of SOEs and agency problems in private firms will reduce tournament incentives. In addition, we found that a split-share structure reform strengthens the positive relationship between CEO pay dispersion and firm performance, although this amplification is weaker in SOEs and stronger in private firms. This was particularly so after the reform where CEO pay dispersion began to have a significant effect on stock-market performance when measured as stock return.

These results remained robust when the endogeneity of pay dispersion was taken into consideration and alternative measures of pay dispersion and firm performance were applied. When we controlled for granting stock options and perks, our results still supported the main findings listed above. Overall, our findings suggest that institutional features such as state ownership, political connections and market reform play an important role in tournament incentives in China; these incentives in turn mitigate the agency problems between shareholders and managers because pay dispersion is appropriately aligned with the CEO's relative talents and contributions, and provide extra incentive to top executives.

Our study contributes to the literature on executive compensation by first focusing on comparisons of the level of executive compensation (e.g., Kaplan, 1994; Abowd and Kaplan, 1999; Conyon and Murphy, 2000; Kato and Long, 2005), and then by exploring the institutional background in which executive pay dispersion arises, and examining its different implications for firms in developed economies like the U.S.

Second, we extend the extant literature on the theory of executive incentive. Prior studies have examined whether executive pay dispersion provides a tournament incentive (Lazear and Rosen, 1981; Conyon, Peck and Sadler, 2001; Rajgopal and Srinivasan, 2006; Kale et al., 2009; Bebchuk et al., 2011), but the evidence is mixed, because tournaments should depend on their economic value and cultural environments (Burns et al., 2011). Some researchers have found the executive pay gap to be positively associated with firm performance in China's firms (Lin and Lu, 2009; Chen et al., 2011a), indicating that Chinese cultural values such as collectivism, and firm characteristics such as managerial power, have a substantial effect on tournament incentives. In addition to examining the effect of ownership types on 
executive pay dispersion, our study explores deeper reasons that shape tournament incentives in different types of firms, and examines other institutional features in China such as political connections and the influence of split-share structure reform in China.

Third, we contribute to the emerging debate on the pay gap between CEOs and other employees since the 2007-2008 global financial crisis, and whether the pay gap should be regulated (Conyon et al., 2009; Fahlenbrach and Stulz, 2009; Core and Guay, 2010; Garner and Kim, 2010). Questions about the appropriate level and structure of executive compensation as an incentive mechanism for better firm performance still exist, as does the question of whether tournament theory even holds as an explanation for the large CEO pay gap found in the U.S. and elsewhere. The effect of pay restrictions imposed by regulators might be traded off by limiting tournament incentives.

The rest of the paper proceeds as follows: Section 2 describes the background and develops hypotheses; Section 3 provides a description of data and methodology; Section 4 discusses empirical results; Section 5 presents robustness tests; and Section 6 draws some conclusions from the findings.

\section{Background and hypothesis}

\subsection{Executive pay dispersion and firm performance in China}

A performance-based contract links managerial compensation to firm performance; this can tempt managers to manipulate the output level when performance is unobservable (Kale et al., 2009). Rank-order tournaments solve this problem in that tournament commitments are set in advance, which is why Lazear and Rosen (1981) proposed that setting a large pay gap can mitigate agency problems when monitoring costs are too high. This large pay dispersion between the CEO and other executives is regarded as a "prize" that provides executives with incentives to compete, and in turn to increase firm performance. Some implications of the effects of pay dispersion on firm performance have been discussed in previous studies. In particular, Kale et al. (2009) find that the CEO pay gap exerts a positive effect on firm performance (measured as return on assets and Tobin's Q). It is argued that in China, the corporate governance environment is less efficient, and outside stakeholders will focus on 
internal monitoring mechanisms to set a larger pay dispersion and an efficient pay scheme. Within a sample of Chinese listed firms, Chen et al. (2011a) document that pay dispersion is positively related to earnings per share (EPS), while Lin and Lu (2009) find that the pay gap is positively related to return on equity. Based on this discussion, we conjecture that a larger pay dispersion will be optimal for creating an incentive, and provide the following hypothesis:

H1: The executive pay dispersion is positively associated with firm performance.

\subsection{The executive incentive, pay dispersion and institutional environment in China}

If CEO pay dispersion is an important source of tournament incentives for managers, then the motivations that a tournament initiates, as well as its consequences, should be related not only to firm characteristics (e.g., Kale et al., 2009), but also to the firm's institutional environment. Previous research has found that the ratio of CEO compensation to non-CEO executive compensation varies significantly across firms, as well as across country and cultural variables (Burns et al., 2012). This study examines whether several key institutional features in China's emerging markets influence the incentive provided by executive pay dispersion.

\subsubsection{SOEs' multiple objectives in China}

After 1978, when the Chinese government began to transform the original planned economy into a market-oriented economy, state-owned firms were corporatized and privatized, and some were listed on either of the two stock exchanges in Shanghai and Shenzhen. Even though these privatized or carved-out state owned enterprises (SOEs) were transmitted to act as their counterparts in western countries, with investment and financing decision-making decentralized from state to firm level, they inherited the responsibilities of their predecessors by taking over a wide range of social and political goals in addition to just maximizing shareholder value.

In general, a salient feature of state ownership is the existence of multiple objectives. As SOEs are controlled by the government, their decisions are subject to the influence of the government; thus, SOEs can be understood as agents of the government in the capital market. Moreover, because these SOEs receive policy and financial support from the government, 
they are also required to satisfy social objectives such as stable employment levels and social stability, and political objectives such as controlling sensitive industries by creating monopolies. Unlike a typical shareholder in market economies, the state shareholders in China face the multiple challenges of increasing production and maintaining social stability. In particular, multi-task theory has been offered to capture the trade-off between production and social stability (Bai et al., 2000). Given these multiple objectives, the Chinese government has imposed restrictions on the pay gap between executives and ordinary workers since the 1980s (Chen et al., 2010; Firth et al., 2010). Meanwhile, SOEs have put more emphasis on guaranteeing workers lifetime employment, paying for health care and education for their children and honoring their commitment to a large number of retired former employees, which in turn contributes to social stability (Bai et al., 2006). State shareholders placing greater importance on the objective of maintaining social and political stability, rather than improving economic performance (Chang and Wong, 2009), will tend to reduce the effectiveness of executive incentives, including pay dispersion as a tournament incentive to improve firm performance.

Alternative incentives also exist within SOEs. For example, gaining political promotion in China's giant government hierarchy may provide a stronger incentive for firm performance (Cao et al., 2011b); perks are more likely to motivate managers to work for the interests of shareholders in China (Chen et al., 2010; Adithipyangkul et al., 2011); top managers may take advantage of their position or abuse managerial power for personal gain or fame, and to circumvent any restrictions on pay, etc. Therefore, explicit compensation that interacts with other incentives might be influenced significantly by the fact that the firm is controlled by the state.

Therefore, we conjecture that executive pay dispersion would provide less tournament incentive for improving firm performance in SOEs than in private firms because SOEs are responsible for satisfying multiple economic and social goals imposed by governments. Thus we suggest the following hypothesis:

H2: The positive association between pay dispersion and firm performance is weaker in SOES. 


\subsubsection{Political connections}

Political connection is a common phenomenon across the world in publicly listed firms, particularly those with a concentrated ownership structure and a weak corporate governance system (Faccio, 2006; Chen et al., 2011b). Some evidence suggests that political connection can bring benefits to companies by accessing the key resources controlled and allocated by the government, including bank loans, favorable tax treatment, preferential corporate bailouts and government subsidies (Faccio et al., 2006; Li et al., 2008). In this sense, executive incentive is less aligned to firm performance because firms with political connections rely less on their executives' performance to evaluate them. In addition, politically connected CEOs are likely to entrench themselves by providing unique political capital; moreover, they face a lower replacement probability and require higher compensation (Aslan and Grinstein, 2011; Cao et al., 2012).

On this basis we conjecture that pay dispersion in firms with political connections is steeper; the higher compensation offered in firms with political connections may reflect rents captured by the CEO, and thus they can be viewed as a product of agency (governance) problems. Executives can win the tournament "prize" by connecting with governments rather than exerting more effort, which will reduce tournament incentives as a means of improving firm performance (Chen et al., 2011a).

In addition, previous studies have focused on the roles played by CEOs with political connections in private firms (Li et al., 2008; Chen et al., 2010; Cao et al., 2012). Researchers have argued that private firms, rather than SOEs, are chosen as the sample for studying political connections because at the time they were formed, SOEs naturally built connections with the government, and it seems difficult to distinguish whether political capital in SOEs comes from the nature of state ownership or the political connections of executives and boards. However, private firms have their own objectives for maximizing market value, and are not bearing the monitoring of government regulations, so the favorable treatment they receive from government should be attributed to politically connected executives. Therefore, a CEO's political connection is expected to have a substantial effect in private firms. We formulate our hypothesis as follows: 
H3: The positive association between pay dispersion and firm performance is weaker in firms where the CEO is politically connected, especially in private firms.

\subsubsection{Market reforms}

Evidence shows that market developments such as better investor protection, stronger legal enforcement and greater market competition, leads to increasing equity financing and firm value (La Porta et al., 1998, 2002). Then those shareholders who face more-intense market competition will tend to offer steeper incentives and higher compensation, and thus induce greater effort. For example, Bebchuk and Fried $(2003,2004)$ find a growing level of executive compensation in the U.S. in the 1990s. Gabaix and Landier (2008) and Hubbard and Palia (1995) argue that market competition requires executives to have more managerial talent and take higher risks, and thus should receive higher compensation.

In a market economy, to ensure that executives are appropriately motivated and that their talent is successfully acquired and retained, shareholders must provide higher compensation in an explicit contract. Thus, along with the progress of market-oriented reforms in China, we expect the dispersion of executive pay to grow and provide more incentive to improve firm performance. For example, in April 2005, China's capital market launched a split-share structure reform aimed at converting non-tradable shares (typically held by the state and legal persons) into tradable shares. This reform has induced the development of a more marketoriented compensation plan and increased market competition (Li et al., 2011). Hence, we provide the following hypothesis:

H4: The positive association between pay dispersion and firm performance has become stronger since the split-share structure reform was launched.

\section{Data and model}

\subsection{The sample}

Our empirical tests are based on all Chinese firms listed on the Shanghai and Shenzhen stock exchanges between 2005 and 2010. Our sample year starts in 2005, when compensation for individual executives (including CEO, CFO, Chairman, and other executives) began to be 
disclosed in annual reports ${ }^{3}$. Before 2005, the listed firms only disclosed the aggregate payment of the top three executives. We excluded firms flagged with ST and ${ }^{*} \mathrm{ST}$ from our total population, as this denotes special treatment due to irregularity in financial reporting, and negative profit for two or three consecutive years. We also excluded firms in the finance industry because of their unique accounting standards, and firms with missing observations on the main variables used in our analysis. Our final sample consists of 7,811 firm-year observations. Executive compensation, corporate governance and financial data for the firms were obtained from the firms' annual reports and the CSMAR database.

\subsection{Variable definition}

CEO pay dispersion

Following Kale et al. (2009) and Bebchuk et al. (2011), we adopted two primary measurements for tournament incentives. The first measurement, GAP, is defined as the log of difference between CEO pay and the median pay of all other executives in the top management team (pay gap). Specifically:

\section{$G A P=\log ($ Total compensation of CEO-Median of total compensation of other executives in the firm year)}

The second measurement, CEO pay slice (CPS), is computed as the fraction of aggregate compensation of the top five members of the executive team that is captured by the CEO.

$$
\text { CPS = Total compensation of CEO / total compensation of top five executives }
$$

An executive's total compensation is the sum of salary, bonuses and other cash compensation. This compensation does not include long-term incentives such as stock options and restricted stocks, because these are rarely exercised in China ${ }^{4}$.

\section{Firm performance}

Our measures of firm performance are return on assets (ROA), firm value (Tobin's Q), stock returns (RET) and return on sales (ROS), defined respectively as the ratio of net income to the book value of total assets, the ratio of the sum of market value of equity and the book value of debt to total assets, firm annual stock returns and the ratio of net income to total

\footnotetext{
${ }^{3}$ China's listed firms only disclosed a small portion of individual CEO pay until 2005.

${ }^{4}$ The stock option and another component of CEO compensation, perks, will be discussed in the additional tests later in this paper.
} 
sales.

We also include CEO age, CEO tenure, CEO duality, firm size, board size, board composition, leverage, largest shareholder ownership and future investment opportunity as control variables. Appendix A.1 provides definitions for all variables.

\section{Results}

\subsection{Summary statistics}

Table 1 shows the summary statistics of our sample, including all the variables we use for both univariate and multivariate tests. The results show that the mean (median) of CEO pay is $448,546(302,200) \mathrm{RMB}$, which is about five times the average CEO pay of $85,000(60,000)$ RMB reported by Firth et al. (2007) for the period between 1998 and 2000. Actually, the CEO pay increased almost five times between 2005 and 2010. The average CEO pay slice is $31.88 \%$, which indicates that total CEO compensation accounts for almost one-third of total compensation of the top five paid executives. This figure is close, although it's still lower than the $35.70 \%$ reported for U.S. executives by Bebchuk et al. (2011). Additionally, the board size averages 9.31 in China, with 3.32 serving as independent directors. The average proportion of independent directors is $35.66 \%$, which satisfies the requirements of the China Securities Regulatory Commission (CSRS) that independent directors must account for at least one-third of the total numbers on boards for all listed firms. In the table's last panel, we show the distribution of the firms. In our sample in particular there are 834 firm-year observations of politically connected SOEs, and 825 politically connected private firms.

\section{Table 1. Summary Statistics}

\begin{tabular}{lllll}
\hline Variables & Mean & Median & Lower quartile & Higher quartile \\
\hline $\begin{array}{l}\text { Panel A: Executive compensation } \\
\text { CEO pay }\end{array}$ & 448,546 & 302,200 & 170,000 & 515,000 \\
$\begin{array}{l}\text { Total of top five executives' pay } \\
\text { Panel B: CEO pay dispersion }\end{array}$ & $1,837,765$ & $1,296,050$ & 760,000 & $2,150,000$ \\
$\begin{array}{l}\text { Pay gap } \\
\text { CEO pay slice (CPS) \% }\end{array}$ & 250,868 & 120,050 & 58,100 & 245,000 \\
Panel C: Firm performance & 31.88 & 28.18 & 24.00 & 35.58 \\
ROA (\%) & & & & \\
Tobin's Q & 3.38 & 3.63 & 1.34 & 6.49 \\
RET (\%) & 1.77 & 1.42 & 1.08 & 1.98 \\
ROS (\%) & 55.97 & 26.75 & -25.65 & 114.42 \\
Panel D: CEO characteristics & 7.21 & 5.80 & 2.07 & 12.57 \\
CEO age & & & & \\
CEO tenure & 46.67 & 46 & 42 & 51 \\
& 3.07 & 2.5 & 1 & 4.5 \\
\hline
\end{tabular}




\begin{tabular}{|c|c|c|c|c|}
\hline CEO duality & 0.16 & 0 & 0 & 0 \\
\hline New CEO & 0.17 & 0 & 0 & 0 \\
\hline Retiring CEO & 0.04 & 0 & 0 & 0 \\
\hline Inside CEO & 0.72 & 1 & 0 & 1 \\
\hline Number of executives (Novp) & 6.69 & 6 & 5 & 8 \\
\hline \multicolumn{5}{|c|}{ Panel D: Firm characteristics and corporate governance } \\
\hline Firm size (millions) & 2,780 & 2,000 & 1,010 & 4,460 \\
\hline Leverage & 48.26 & 49.33 & 33.53 & 62.87 \\
\hline Board size & 9.31 & 9 & 9 & 10 \\
\hline Independent directors & 3.32 & 3 & 3 & 4 \\
\hline Largest (\%) & 37.77 & 36 & 25.22 & 49.55 \\
\hline Managerial ownership (\%) & 0.0585 & 0.0329 & 0.00875 & 0.1413 \\
\hline \multicolumn{5}{|l|}{ Panel E: firm type distributions } \\
\hline & \multicolumn{2}{|c|}{ SOEs } & \multicolumn{2}{|c|}{ Private firms } \\
\hline & $\mathrm{PC}$ & Non-PC & PC & Non-PC \\
\hline Observations & 834 & 3943 & 825 & 2579 \\
\hline
\end{tabular}

Pay gap is defined as the difference in compensation between the CEO and the median level of other executives. All the other variables are defined in Appendix A.1. All the value variables are in terms of China's currency, the RMB.

\subsection{Ownership structure, CEO pay dispersion and firm performance}

\subsubsection{CEO pay dispersion and firm performance}

To provide some primary evidence to support our hypotheses we conduct the following regression to examine whether tournament theory applies in China, reflected by a positive relation between CEO pay dispersion and firm performance:

$$
\begin{aligned}
\text { PERF }_{i t}= & \beta_{0}+\beta_{1} \text { PayDispersion }_{i t}+\beta_{2} \text { Size }_{i t}+\beta_{3} \text { Leverage }_{i t} \\
& +\beta_{4} \text { Largest }_{i t}+\beta_{5} \text { Board }_{i t}+\beta_{6} \text { Indep }_{i t}+\varepsilon_{i t}
\end{aligned}
$$

where $P E R F$ is firm performance. We use four measures as the proxies for firm performance: return on assets (ROA), Tobin's Q (Q), stock returns (RET) and return on sales (ROS). PayDispersion is CEO pay dispersion, measured by the GAP and CPS in each regression, respectively. Size is the log of the firm's total assets. Leverage is the ratio of total debt to total assets. Largest is the proportion of shares held by the largest shareholder. Board is the log of the numbers of directors on the board. Indep is the proportion of independent directors.

Table 2 presents the results of the relationship between CEO pay dispersion and firm performance. Two measures for CEO pay dispersion are applied in the regression: GAP and CPS. As shown in Table 2, the coefficients on CEO pay dispersion are all estimated to be positive and statistically significant (except when stock returns are used as the measurement of firm performance), which indicates that the pay differential effectively provides internal 
incentives for executives to deliver good firm performance; this is consistent with the prediction of tournament theory. Among the control variables, we find coefficients that are consistent with those reported in previous studies (Chen et al., 2009). On one hand, accounting performance (ROA and ROS) is positively related to firm size and largest shareholder ownership, but negatively related to firm leverage level. On the other hand, firm value (Tobin's Q) is negatively related to firm size and largest shareholder ownership. In addition, the results show that across these four specifications the independent directors most significantly affect firm value rather than firm accounting or market performance. These results are in line with the fact that with China's poor corporate governance system and inadequate outside investor protection, shareholders of publicly held firms feel unsure of external mechanisms, and therefore place more emphasis on managerial compensation because it is believed to be the most effective internal mechanism available (Murphy, 1999; Firth et al., 2006b).

Table 2. Regression of pay-dispersion effect on firm performance

\begin{tabular}{|c|c|c|c|c|}
\hline \multicolumn{5}{|c|}{ Panel A: GAP is used as the CEO pay-dispersion measurement } \\
\hline Dependent variable & ROA & Q & RET & ROS \\
\hline Constant & $-0.20 * * *(-8.52)$ & $5.63 * * *(13.86)$ & $0.16(0.65)$ & $-0.52 * * *(-8.84)$ \\
\hline GAP & $0.09 * * *(10.41)$ & $0.12 * * *(8.20)$ & $0.01(1.22)$ & $0.05 * * *(8.76)$ \\
\hline Size & $0.09 * * *(7.78)$ & $-0.21 * * *(-8.97)$ & $0.03 * *(2.35)$ & $0.03 * * *(9.23)$ \\
\hline Leverage & $-0.15 * * *(-19.23)$ & $-0.64 * * *(-3.07)$ & $0.06(1.02)$ & $-0.32 * * *(-18.94)$ \\
\hline Largest & $0.05 * * *(7.01)$ & $-0.07 * * *(-6.05)$ & $-0.03 * * *(-4.67)$ & $0.08 * * *(4.73)$ \\
\hline Board & $0.03(0.58)$ & $-0.17 *(-1.92)$ & $-0.03(-0.60)$ & $-0.04(-0.34)$ \\
\hline Indep & $-0.01(-0.50)$ & $1.16^{* * *}(3.30)$ & $-0.30(-1.34)$ & $-0.02(-0.40)$ \\
\hline Year fixed effect & Included & Included & Included & Included \\
\hline Industry fixed effect & Included & Included & Included & Included \\
\hline Area fixed effect & Included & Included & Included & Included \\
\hline Adj $R^{2}$ & 0.23 & 0.10 & 0.03 & 0.19 \\
\hline Obs & 7811 & 7811 & 7811 & 7811 \\
\hline \multicolumn{5}{|c|}{ Panel B: $C P S$ is used as the CEO pay-dispersion measurement } \\
\hline Dependent variable & ROA & $\mathrm{Q}$ & RET & ROS \\
\hline Constant & $-0.15 * * *(-6.36)$ & $5.82 * * *(14.85)$ & $0.55 * * *(2.71)$ & $-0.53 * * *(-9.08)$ \\
\hline CPS & $0.05 * *(2.44)$ & $0.02 * *(2.16)$ & $0.02(1.32)$ & $0.12 * *(2.47)$ \\
\hline Size & $0.02 * * *(10.43)$ & $-0.16 * * *(-7.72)$ & $0.02(1.30)$ & $0.04 * * *(12.74)$ \\
\hline Leverage & $-0.16 * * *(-19.09)$ & $-0.70 * * *(-3.48)$ & $0.08(1.23)$ & $-0.34 * * *(-20.62)$ \\
\hline Largest & $0.04 * * *(5.69)$ & $-0.08 * * *(-7.42)$ & $-0.03 * * *(-3.81)$ & $0.04 * * *(2.67)$ \\
\hline Board & $0.03(0.63)$ & $-0.18 * *(-2.02)$ & $-0.05(-0.87)$ & $0.02(0.02)$ \\
\hline Indep & $-0.05(-0.26)$ & $1.26 * * *(3.72)$ & $-0.31(-1.52)$ & $-0.02(-0.26)$ \\
\hline Year fixed effect & Included & Included & Included & Included \\
\hline Industry fixed effect & Included & Included & Included & Included \\
\hline Area fixed effect & Included & Included & Included & Included \\
\hline $\operatorname{Adj} R^{2}$ & 0.20 & 0.10 & 0.03 & 0.19 \\
\hline Obs & 7811 & 7811 & 7811 & 7811 \\
\hline
\end{tabular}


The dependent variable is firm performance, measured by $R O A$, Tobin's Q, stock returns and ROS. Pay dispersion is measured by either GAP or CPS. Size is the log of a firm's total assets. Leverage is the ratio of total debts to total assets. Largest is the proportion of shares held by the largest shareholders. Board is the log of the total number of directors on a firm's board. Indep is the proportion of independent directors on a firm's board.

T-statistics are in parentheses, computed using the White (1980) heteroscedasticity robust standard error, clustered by firm.

$*, * *$ and $* * *$ indicate significance at the $10 \%, 5 \%$ and $1 \%$ levels, respectively.

\subsubsection{Ownership structure and relation between pay dispersion and firm performance}

In this section we analyze whether tournament incentives differ across the ownership structure by dividing our total sample into SOEs and private firms. A firm is identified as an SOE if the government is the controlling shareholder. To take a primary look at the effect of pay dispersion on firm performance, and the effect of ownership structure on tournament incentives, we conduct multivariate analysis to test our hypotheses and provide evidence for the association between CEO pay dispersion and firm performance between SOEs and private firms. To do so, we run the following regression:

$$
\begin{aligned}
\text { PERF }_{i t}= & \beta_{0}+\beta_{1} \text { PayDispersion }_{i t}+\beta_{2} \text { PayDispersion }_{i t} * \text { State }_{i t}+\beta_{3} \text { State }_{i t}+\beta_{4} \text { Size }_{i t} \\
& +\beta_{5} \text { Leverage }_{i t}+\beta_{6} \text { Largest }_{i t}+\beta_{7} \text { Board }_{i t}+\beta_{8} \text { Indep }_{i t}+\varepsilon_{i t}
\end{aligned}
$$

where $P E R F$ is firm performance, measured as return on assets (ROA), Tobin's Q (Q), stock returns (RET) and return on sales (ROS) in each specification. State is a dummy variable equal to 1 if the firm is ultimately controlled by the government. All the other variables are defined the same as those in Equation (1). The results of this regression are shown in Table 3.

Table 3. Regression of pay-dispersion effect on firm performance between SOEs and private firms

\begin{tabular}{lllll}
\hline \multicolumn{2}{l}{ Panel A: GAP is used as the CEO pay-dispersion measurement } & \multicolumn{1}{c}{ RET } & \multicolumn{1}{c}{ ROS } \\
\hline Dependent variable & \multicolumn{1}{c}{ ROA } & \multicolumn{1}{c}{$\mathrm{Q}$} & \multicolumn{1}{c}{ RE* } & \multicolumn{1}{c}{ R } \\
Constant & $-0.49 * * *(-7.05)$ & $5.01 * * *(6.31)$ & $0.81 * *(2.98)$ & $-0.59 * *(-5.74)$ \\
GAP & $0.08 * * *(5.20)$ & $0.15 * * *(8.22)$ & $0.09(0.55)$ & $0.05 * * *(5.46)$ \\
GAP*State & $-0.03 * * *(-2.71)$ & $-0.03 * *(-2.45)$ & $-0.08(-0.45)$ & $-0.01 * *(-2.29)$ \\
State & $0.03(1.62)$ & $0.35(1.35)$ & $0.05(0.19)$ & $0.09 * * *(2.99)$ \\
Size & $0.03 * * *(3.97)$ & $-0.20 * * *(-6.38)$ & $0.09(0.90)$ & $0.03 * * *(3.27)$ \\
Leverage & $-0.39 * * *(-2.86)$ & $-0.61 * * *(-3.77)$ & $0.06(1.04)$ & $-0.32 * * *(-7.57)$ \\
Largest & $0.03 * * *(3.36)$ & $-0.69 * * *(-8.15)$ & $-0.33 * * *(-4.23)$ & $0.08 * * *(7.87)$ \\
Board & $0.02 * *(2.58)$ & $-0.17 * * *(-2.65)$ & $-0.07(-1.45)$ & $0.02(1.41)$ \\
Indep & $-0.04(-1.49)$ & $1.01 * * *(3.82)$ & $-0.37 *(-1.85)$ & $-0.03(-0.82)$ \\
Year fixed effect & Included & Included & Included & Included \\
Industry fixed effect & Included & Included & Included & Included \\
Area fixed effect & Included & Included & Included & Included
\end{tabular}




\begin{tabular}{|c|c|c|c|c|}
\hline $\begin{array}{l}\text { Adj } R^{2} \\
\text { Obs }\end{array}$ & $\begin{array}{l}0.42 \\
7811 \\
\end{array}$ & $\begin{array}{l}0.15 \\
7811 \\
\end{array}$ & $\begin{array}{l}0.03 \\
7811 \\
\end{array}$ & $\begin{array}{l}0.20 \\
7811 \\
\end{array}$ \\
\hline \multicolumn{5}{|c|}{ Panel B: CPS is used as the CEO pay-dispersion measurement } \\
\hline Dependent variable & ROA & $\mathrm{Q}$ & RET & ROS \\
\hline Constant & $-0.18 * * *(-7.46)$ & $5.65 * * *(4.55)$ & $0.76 * * *(3.46)$ & $-0.57 * * *(-9.90)$ \\
\hline CPS & $0.07 * *(2.01)$ & $0.12 * * *(2.79)$ & $0.15(0.61)$ & $0.08 * * *(2.77)$ \\
\hline CPS*State & $-0.02 * *(-2.11)$ & $-0.07 * *(-2.45)$ & $-0.03(-0.12)$ & $-0.05 * *(-2.18)$ \\
\hline State & $0.02(0.47)$ & $0.05(0.87)$ & $0.05(0.49)$ & $0.04 * * *(5.03)$ \\
\hline Size & $0.02 * * *(3.19)$ & $-0.15 * * *(-7.61)$ & $0.08(0.85)$ & $0.03 * * *(3.57)$ \\
\hline Leverage & $-0.16 * * *(-8.68)$ & $-0.69 * * *(-3.44)$ & $0.06(1.01)$ & $-0.32 * * *(-9.94)$ \\
\hline Largest & $0.05 * * *(7.00)$ & $-0.81 * * *(-7.00)$ & $-0.32 * * *(-4.19)$ & $0.06 * * *(3.93)$ \\
\hline Board & $0.01 *(1.80)$ & $-0.15(-1.61)$ & $-0.07(-1.49)$ & $0.01(0.77)$ \\
\hline Indep & $-0.02(-0.42)$ & $1.24 * * *(3.63)$ & $-0.34 *(-1.65)$ & $-0.02(-0.35)$ \\
\hline Year fixed effect & Included & Included & Included & Included \\
\hline Industry fixed effect & Included & Included & Included & Included \\
\hline Area fixed effect & Included & Included & Included & Included \\
\hline Adj $R^{2}$ & 0.23 & 0.10 & 0.03 & 0.19 \\
\hline Obs & 7811 & 7811 & 7811 & 7811 \\
\hline
\end{tabular}

The dependent variable is firm performance, measured by ROA, Tobin's Q, stock returns and ROS. Pay dispersion is measured by either GAP or CPS. State is a dummy variable coded 1 for state-controlled firms and 0 for private firms. Size is the log of a firm's total assets. Leverage is the ratio of total debts to total assets. Largest is the proportion of shares held by the largest shareholders. Board is the log of the total number of directors on a firm's board. Indep is the proportion of independent directors on a firm's board.

T-statistics are in parentheses, computed using the White (1980) heteroscedasticity robust standard error, clustered by firm.

$*, * *$ and $* * *$ indicate significance at the $10 \%, 5 \%$ and $1 \%$ levels, respectively.

Table 3 reports our findings on the effects of pay dispersion on firm performance across different ownership structures. We use four measurements - ROA, Tobin's Q, stock returns, and ROS - as proxies for firm performance. Panel A in the table presents the results using GAP as a measure of pay dispersion, while Panel B uses the CPS. With ROA, Tobin's Q and ROS as measures of firm performance, the coefficients on both pay dispersion measures are positive and significant. This result is consistent when industry-adjusted ROA, Tobin's Q and ROS are used. This indicates that a large pay gap between the CEO and other top executives can provide incentives for the executives to work hard and deliver good firm performance. This result is consistent with our hypothesis that a large CEO pay dispersion can increase firm performance. However, we are more concerned about the results of the interaction terms between pay dispersion and State, since these interaction terms are used to test whether state ownership is associated with a weaker relationship between pay dispersion and firm performance. The results in Table 3 show that the coefficients of these interaction terms are negative and statistically significant, except when stock returns are used as firm performance. This result suggests that $\mathrm{CEO}$ pay dispersion has a positive effect on firm performance in private firms, but that this effect becomes less positive in state-controlled firms. These results 
are in line with our second hypothesis.

As discussed above, we believe that the weaker relationship between CEO pay dispersion and firm performance in SOEs is attributed to the multiple objectives of the state shareholders. However, we have not addressed whether it means that tournament incentives have become inefficient in SOEs in China. To answer this question, we choose the SOE sub-sample to examine the effectiveness of tournament incentives alongside other objectives. Recently Bradshaw et al. (2012) have argued that in SOEs, taxes are a dividend to the state controlling shareholder, but a cost to other shareholders. One of the important political objectives of bureaucrats is to collect higher taxes. If managers of SOEs make tax decisions that are favorable to the government, they are more likely to be promoted in the Chinese bureaucratic hierarchy. Bradshaw et al. (2012) find that SOEs have significantly higher tax rates than nonSOEs, and that the tax rates are negatively associated with stock returns. Following this work, we select the tax-payment rates of the SOEs as a proxy for measuring political objectives other than economic performance. Empirically, we rerun Equation (2) by replacing State dummy with tax payments (using the ratio of the tax payment to total assets as the proxy), and use the SOE sub-sample only. The results are reported in Table 4 below. For the sake of brevity we report only the coefficients of the key variables. Panel A and B show the results using GAP and CPS, respectively, as the measures of CEO pay dispersion, revealing that CEO pay dispersion is positively related to firm performance. The interaction terms between tax payments and CEO pay dispersion are of concern, because the estimated coefficients on interaction terms are generally all negative and statistically significant (except where stock return is used as a dependent variable). This result shows that in SOEs, CEO pay dispersion is less related to firm performance when firms pay higher taxes, indicating that tournament incentives are less effective in SOEs with multiple objectives. Moreover, when the combined effects of both CEO pay dispersion and its interaction with tax payments are calculated, the net results are still positive, indicating that tournament incentives still work in SOEs with multiple objectives, but have a weaker effect.

Table 4. Tournament incentives and tax payments in SOEs

Panel A: Subsample of SOEs

Dependent variable ROA Q




$\begin{array}{lllll}\text { GAP } & 0.12 * * *(5.42) & 0.16 * * *(7.15) & 0.05(0.86) & 0.23 * * *(6.29) \\ \text { Tax } & 0.07 * * *(2.59) & 0.06 * *(2.08) & 0.07(0.50) & 0.02 * * *(3.47) \\ \text { GAP*Tax } & -0.06 * * *(-2.77) & -0.05 * *(-2.02) & -0.02(-1.00) & -0.02 * * *(-3.33)\end{array}$

Other control variables include firm size, leverage, board size, independent directors, largest ownership, year, industry and area fixed effects

\begin{tabular}{lllll} 
Adj R2 & 0.49 & 0.10 & 0.05 & 0.17 \\
Obs & 4777 & 4777 & 4777 & 4777 \\
\hline \multicolumn{2}{l}{ Panel B: Subsample of SOEs } & & & ROS \\
\hline Dependent variable & ROA & Q & RET & $0.15^{* *(2.34)}$ \\
CPS & $0.03^{* * *}(2.73)$ & $0.72 * *(2.77)$ & $-0.32(-0.93)$ & $0.05 * *(2.37)$ \\
Tax & $0.06(0.29)$ & $0.05^{*}(1.75)$ & $-0.02(-1.00)$ & $-0.01 * *(-2.33)$ \\
CPS Tax & $-0.02^{* *(-2.45)}$ & $-0.06(-1.55)$ & $0.02(0.95)$ &
\end{tabular}

Other control variables include firm size, leverage, board size, independent directors, largest ownership, year, industry and area fixed effects

\begin{tabular}{lllll} 
Adj R2 & 0.71 & 0.10 & 0.07 & 0.20 \\
Obs & 4777 & 4777 & 4777 & 4777 \\
\hline
\end{tabular}

The dependent variable is firm performance, measured by $R O A$, Tobin's Q, stock returns and ROS. Pay dispersion is measured by either GAP or CPS. Tax is the ratio of the amount of taxes payouts to total assets. All the other variables are defined as those in the previous tables.

T-statistics are in parentheses, computed using the White (1980) heteroscedasticity robust standard error, clustered by firm.

$*, * *$ and $* * *$ indicate significance at the $10 \%, 5 \%$ and $1 \%$ levels, respectively.

\subsection{Political connection, CEO pay dispersion and firm performance}

This section examines the effect of CEO political connection on the effectiveness of tournament incentives. The definition of CEO political connection is consistent with that of Fan et al. (2007): a CEO is defined as politically connected if the CEO was or is a government official or military official, including the member of the National People's Congress (NPC), the Chinese People's Political Consultative Conference (CPPCC) or the AllChina Federation of Industry and Commerce (ACFIC), or an official of other ministries of the government or military. We are also interested in examining whether this effect varies according to the ownership structure. The main empirical model we estimate is as follows:

$$
\begin{aligned}
\text { PERF }_{i t}= & \beta_{0}+\beta_{1} \text { PayDispersion }_{i t}+\beta_{2} \text { PayDispersion }_{i t} * P C_{i t}+\beta_{3} P C_{i t}+\beta_{4} \text { Size }_{i t} \\
& +\beta_{5} \text { Leverage }_{i t}+\beta_{6} \text { Largest }_{i t}+\beta_{7} \text { Board }_{i t}+\beta_{8} \text { Indep }_{i t}+\varepsilon_{i t}
\end{aligned}
$$

where $P C$ is a dummy variable equal to 1 if the $\mathrm{CEO}$ is politically connected and 0 otherwise. All the other variables are defined as in Equation (2). The results of this regression are reported in Table 5.

Table 5. Regression results of $\mathrm{PC}$ and pay-dispersion effects on firm performance for 
full sample

\begin{tabular}{|c|c|c|c|c|}
\hline \multicolumn{5}{|c|}{ Panel A: GAP is used as the CEO pay-dispersion measurement } \\
\hline Dependent variable & ROA & $\mathrm{Q}$ & RET & ROS \\
\hline Constant & $-0.21 * * *(-9.12)$ & $5.27 * * *(3.48)$ & $0.68 * * *(3.26)$ & $-0.60 * * *(-3.31)$ \\
\hline GAP & $0.07 * * *(5.58)$ & $0.12 * * *(8.38)$ & $0.09(1.03)$ & $0.06 * * *(8.22)$ \\
\hline $\mathrm{GAP} * \mathrm{PC}$ & $-0.03 * *(-2.35)$ & $-0.02 * *(-2.06)$ & $-0.02(-0.32)$ & $-0.03 * * *(-2.58)$ \\
\hline $\mathrm{PC}$ & $0.02(0.28)$ & $0.03(0.34)$ & $0.17(0.34)$ & $0.05(0.45)$ \\
\hline Size & $0.07 * * *(7.11)$ & $-0.20 * * *(-9.32)$ & $0.02(1.53)$ & $0.03 * *(3.58)$ \\
\hline Leverage & $-0.15 * * *(-8.61)$ & $-0.62 * * *(-3.27)$ & $0.07(1.06)$ & $-0.32 * *(-2.17)$ \\
\hline Largest & $0.05 * * *(8.13)$ & $-0.70 * * *(-6.17)$ & $-0.31 * * *(-4.17)$ & $0.07 * * *(4.43)$ \\
\hline Board & $0.05(1.13)$ & $-0.18 * *(-2.01)$ & $-0.05(-1.06)$ & $0.03(0.26)$ \\
\hline Indep & $-0.09(-0.50)$ & $1.01 * * *(2.90)$ & $-0.39 *(-1.92)$ & $-0.02(-0.48)$ \\
\hline Year fixed effect & Included & Included & Included & Included \\
\hline Industry fixed effect & Included & Included & Included & Included \\
\hline Area fixed effect & Included & Included & Included & Included \\
\hline $\operatorname{Adj} R^{2}$ & 0.24 & 0.10 & 0.03 & 0.20 \\
\hline Obs & 7811 & 7811 & 7811 & 7811 \\
\hline \multicolumn{5}{|c|}{ Panel B: $C P S$ is used as the CEO pay-dispersion measurement } \\
\hline Dependent variable & ROA & $\mathrm{Q}$ & RET & $\mathrm{ROS}$ \\
\hline Constant & $-0.15 * * *(-6.45)$ & $5.81 * * *(4.75)$ & $0.67 * * *(3.17)$ & $-0.52 * * *(-9.13)$ \\
\hline CPS & $0.09 * *(2.26)$ & $0.10 * *(2.00)$ & $0.18(1.09)$ & $0.04 * *(2.55)$ \\
\hline CPS *PC & $-0.02 * *(-2.28)$ & $-0.06 * *(-2.37)$ & $-0.12(-0.25)$ & $-0.01 * *(-2.19)$ \\
\hline $\mathrm{PC}$ & $0.03(0.76)$ & $0.03(0.39)$ & $0.03(0.17)$ & $0.02(1.35)$ \\
\hline Size & $0.02 * * *(4.28)$ & $-0.16 * * *(-7.75)$ & $0.02(1.31)$ & $0.03 * * *(2.64)$ \\
\hline Leverage & $-0.16 * * *(-3.00)$ & $-0.70 * * *(-3.48)$ & $0.06(1.04)$ & $-0.34 * * *(-2.80)$ \\
\hline Largest & $0.04 * * *(5.99)$ & $-0.85 * * *(-7.28)$ & $-0.30 * * *(-4.10)$ & $0.05 * * *(3.21)$ \\
\hline Board & $0.04(0.76)$ & $-0.18 * *(-2.00)$ & $-0.05(-1.14)$ & $0.02(0.02)$ \\
\hline Indep & $-0.03(-0.19)$ & $1.26 * * *(3.73)$ & $-0.35 *(-1.72)$ & $-0.01(-0.23)$ \\
\hline Year fixed effect & Included & Included & Included & Included \\
\hline Industry fixed effect & Included & Included & Included & Included \\
\hline Area fixed effect & Included & Included & Included & Included \\
\hline Adj $R^{2}$ & 0.21 & 0.10 & 0.03 & 0.19 \\
\hline Obs & 7811 & 7811 & 7811 & 7811 \\
\hline
\end{tabular}

Firm performance is a dependent variable measured by $R O A$, Tobin's Q, stock returns and ROS. Pay dispersion is measured by either GAP or CPS. $P C$ is a dummy variable coded 1 if the CEO is politically connected and 0 otherwise. Size is the log of a firm's total assets. Leverage is the ratio of total debts to total assets. Largest is the proportion of shares held by the largest shareholders. Tenure is the log of years that a CEO has been in that position. Age is the log of CEO age. Board is the log of the total number of directors on the boards. Indep is the proportion of independent directors on the boards.

The T-statistics are in parentheses and were computed using the White (1980) heteroscedasticity robust standard error, clustered by firm.

$*, * *$ and $* * *$ indicate significance at the $10 \%, 5 \%$, and $1 \%$ levels, respectively.

Table 5 shows that CEO pay dispersion is positively related to firm performance. Here we focus on the coefficients of the interaction terms between PC and CEO pay dispersion. Across all specifications, the estimated coefficients of the interaction terms between CEO pay dispersion and PC are negative and statistically significant (except when stock returns are used as the firm performance). Specifically, in column 1 of Panel A, the estimated coefficient 
of the interaction term is -0.03 with $5 \%$ significance (t-value is -2.35 ); this indicates that the positive effect of CEO pay dispersion on firm performance becomes weaker when the CEO is politically connected, which is consistent with our third hypothesis. In addition, the estimated coefficients of PC are positive and only statistically significant when GAP is used as the measure of CEO pay dispersion (Panel A $)^{5}$. This also suggests that executives could build political connections with the government and "win the contest" without exerting more effort than other executives, thus making tournament incentives weaker. In addition, when a CEO is politically connected, other executives lower in the hierarchy find it more difficult to compete, which makes tournament incentives less attractive.

Furthermore, we divided our sample into two sub-samples that only include SOEs and private firms, respectively, and rerun our Equation (3). From the untabulated results, we find that the negative effect of political connection on the relationship between pay dispersion and firm performance is only significant in privately controlled firms, which supports our third hypothesis. Existing studies that examine the effect of CEO political connection in private firms in China argue that SOEs are ultimately controlled by the government, which naturally leads to features such as political connections (Li et al., 2008), and therefore the effect of politically connected executives will be offset by state ownership. Our results echo that the effect of CEO political connection is more significant in private firms, where the positive association between CEO pay dispersion and firm performance weakens significantly.

\subsection{Reform of split-share structure, pay dispersion and firm performance}

In 2005 a split-share structure reform was launched on the Chinese stock market to transform shares that were non-tradable on the stock exchanges into tradable. This reform started in April 2005 and finished at the end of $2007^{6}$. Before 2005, Chinese stock exchanges were characterized by a split-share structure, where most of the listed firms were either

\footnotetext{
${ }^{5}$ This result indicates that firms with politically connected CEOs may outperform firms with non-politically connected CEOs. Our results differ from Fan et al. (2007), possibly because they used a sample of newly privatized SOEs from 1993 to 2001, while our sample includes both SOEs and private firms and ranges from 2005 to 2010. On the other hand, Fan et al. (2007) focus on the stock-market reaction after listing, while we use the returns and firm value as proxies for firm performance.

${ }^{6}$ At the end of 2007, almost all listed firms in China complied with the split-share structure reform, and such firms now represent $98 \%$ of the total market capitalization.
} 
directly or indirectly controlled by the government, and the shares held by the government's controlling shareholders were non-tradable (these accounted for almost two-thirds of the total shares outstanding ${ }^{7}$ ). Holders of non-tradable shares were less likely to benefit from share trading on the stock market, and thus tended to focus on accounting performance rather than market performance; this was not necessarily consistent with the interests of minority shareholders. Moreover, the controlling shareholders extracted private benefits by setting operational objectives that were not conducive to the wealth of minority shareholders, but only their own private interests (Cao et al., 2011a).

However, after the split-share structure reform, all common shares outstanding circulated on the stock market, and the interests of controlling shareholders and minority shareholders became aligned to some extent ( $\mathrm{Li}$ et al., 2011). In other words, all types of shareholders could now benefit from improving stock market performance. Thus, evaluations of firm performance become more market-oriented and measurable, and stock returns become increasingly important. On this basis, therefore, we conjecture that listed firms began to transfer the interest on accounting performance to stock returns, and indeed may have reacted actively to stock returns after the split-share structure reform. However, since a complicated agency problem still exists in the SOEs due to their multiple social responsibilities in addition to their obligations to maximize shareholders' value, we expect that the positive effect of share reform will be greater in private firms than in SOEs.

To examine the effect of split-share structure reform on the relationship between CEO pay dispersion and firm performance, we conduct multivariate tests. Explicitly, we identify the completion time of the reform for each firm as the benchmark to divide our total sample into before- and after-reform sub-samples.

In particular, we apply a regression analysis and rerun Equation (2) by adding the dummy variable Reform, which is equal to 1 for the post-reform period and 0 otherwise, and interact it with CEO pay dispersion. The estimated results, reported in Table 6, provide some evidence to support our hypotheses. In general, the coefficients on two CEO pay-dispersion measures are positive and statistically significant, which supports our first hypothesis,

\footnotetext{
${ }^{7}$ These non-tradable shares can only be transferred after approval by the China Securities Regulatory Commission (CSRC).
} 
whereas the negative coefficients on the interaction terms between CEO pay dispersion and state ownership indicate that tournament incentives are weaker in SOEs, supporting our second hypothesis. Some interesting evidence has emerged regarding the effects of the reform, particularly in Panel A, where the CEO pay gap is used as CEO pay dispersion, and the estimated coefficients of the interaction terms between CEO pay dispersion and the Reform dummy are positive and significant when Tobin's Q and stock returns are used as proxies for firm performance. This indicates that since the market development, the positive association between CEO pay dispersion and firm performance has been strengthened; this is consistent with our fourth hypothesis. Moreover, the negative coefficients on GAP*State*Reform are consistent with our hypothesis that the positive effect of the reform on the relationship between CEO pay dispersion and firm performance is stronger in private firms than in SOEs; this result holds both before and after the market reform. Overall, the general results in Table 6 suggest that the effect of tournament incentives on firm performance has been enhanced by the market development, but the amplification is still weaker in SOEs relative to private firms. The results also suggest that executive pay dispersion starts to show a positive effect on stock returns after the reform, but not before.

Furthermore, we try to treat the split-share structure reform as a policy variable that can provide an exogenous source of variation in explanatory variables. We revise the sample used in Table 6 and rerun the equation based on a new sample that includes the period from the first year of the reform to the year of its completion. This reduced the sample size from the original 7,811 firm-year observations to 3,573. These untabulated results are broadly similar to those reported in Table 6; this, again, provides supports to our hypotheses after controlling for the endogeneity issue.

Table 6. Effect of reform on the relationship between pay dispersion and firm performance

\begin{tabular}{|c|c|c|c|c|}
\hline \multicolumn{5}{|c|}{ Panel A: GAP is used as the CEO pay-dispersion measurement } \\
\hline Dependent variable & ROA & $\mathrm{Q}$ & RET & ROS \\
\hline Constant & $-0.23 * * *(-7.94)$ & $5.05 * * *(8.64)$ & $-0.13(-0.53)$ & $-0.61 * * *(-8.97)$ \\
\hline GAP & $0.06 * * *(5.86)$ & $0.15 * * *(6.12)$ & $0.07(1.18)$ & $0.07 * * *(3.42)$ \\
\hline State & $0.03(1.06)$ & $0.45(1.26)$ & $0.10 * * *(2.87)$ & $0.10 * *(2.11)$ \\
\hline Reform & $0.03 *(1.90)$ & $1.16 * * *(5.38)$ & $1.73 * * *(8.46)$ & $0.03(0.73)$ \\
\hline GAP*State & $-0.02 * *(-2.27)$ & $-0.03 * *(-2.10)$ & $-0.03(-0.17)$ & $-0.02 * * *(-2.78)$ \\
\hline GAP*Reform & $0.02(1.37)$ & $0.06 * * *(3.29)$ & $0.12 * * *(7.21)$ & $0.01 * *(2.36)$ \\
\hline
\end{tabular}




\begin{tabular}{|c|c|c|c|c|}
\hline GAP*State*Reform & $-0.01 * *(-1.96)$ & $-0.03 * * *(-2.74)$ & $-0.03 * * *(2.95)$ & $-0.02 * *(-2.01)$ \\
\hline Size & $0.02 * * *(7.98)$ & $-0.23 * * *(-9.50)$ & $-0.02(-0.20)$ & $0.03 * * *(9.16)$ \\
\hline Leverage & $-0.15 * * *(-8.23)$ & $-0.50 * * *(-2.87)$ & $0.12 *(1.80)$ & $-0.32 * * *(-9.17)$ \\
\hline Largest & $0.06 * * *(8.67)$ & $-0.66 * * *(-5.80)$ & $-0.28 * * *(-3.65)$ & $0.08 * * *(4.78)$ \\
\hline Board & $0.02 *(1.87)$ & $-0.09(-0.92)$ & $-0.03(-0.67)$ & $0.01(0.89)$ \\
\hline Indep & $-0.01(-0.63)$ & $0.69 * *(1.99)$ & $-0.57 * * *(-2.73)$ & $-0.03(-0.56)$ \\
\hline Year fixed effect & Included & Included & Included & Included \\
\hline Industry fixed effect & Included & Included & Included & Included \\
\hline Area fixed effect & Included & Included & Included & Included \\
\hline $\operatorname{Adj} R^{2}$ & 0.25 & 0.15 & 0.02 & 0.20 \\
\hline Obs & 7811 & 7811 & 7811 & 7811 \\
\hline \multicolumn{5}{|c|}{ Panel B: $C P S$ is used as the CEO pay-dispersion measurement } \\
\hline Dependent variable & ROA & $\mathrm{Q}$ & RET & ROS \\
\hline Constant & $-0.17 * * *(-7.25)$ & $6.05 * * *(9.55)$ & $0.97 * * *(4.28)$ & $-0.56 * * *(-9.60)$ \\
\hline CPS & $0.06 * * *(2.86)$ & $0.07 * *(2.05)$ & $0.19(0.86)$ & $0.05 * * *(2.62)$ \\
\hline State & $0.02(1.15)$ & $0.02(0.18)$ & $0.06 *(1.71)$ & $0.05(1.60)$ \\
\hline Reform & $0.03(0.98)$ & $0.43 * * *(8.72)$ & $0.19 * *(2.24)$ & $0.01(1.18)$ \\
\hline CPS*State & $-0.02 * *(-2.37)$ & $-0.03 * *(-2.24)$ & $-0.03(-0.27)$ & $-0.02 * * *(-2.74)$ \\
\hline CPS*Reform & $0.02 *(1.91)$ & $0.18(1.15)$ & $0.09 * *(2.33)$ & $0.05 *(1.81)$ \\
\hline CPS*State*Reform & $-0.01 * * *(-2.78)$ & $-0.01 * *(-2.06)$ & $-0.10 * * *(-2.68)$ & $-0.01 * *(-2.42)$ \\
\hline Size & $0.02 * * *(10.85)$ & $-0.19 * * *(-9.45)$ & $-0.01(-1.18)$ & $0.04 * * *(13.13)$ \\
\hline Leverage & $-0.16 * * *(-8.43)$ & $-0.56 * * *(-3.11)$ & $0.10(1.56)$ & $-0.32 * * *(-9.59)$ \\
\hline Largest & $0.05 * * *(7.02)$ & $-0.75 * * *(-6.49)$ & $-0.27 * * *(-3.43)$ & $0.06 * * *(3.93)$ \\
\hline Board & $0.02 *(1.85)$ & $-0.05(-0.58)$ & $-0.03(-0.65)$ & $0.02(0.82)$ \\
\hline Indep & $-0.01(-0.45)$ & $0.92 * * *(2.74)$ & $-0.53 * *(-2.55)$ & $-0.02(-0.39)$ \\
\hline Year fixed effect & Included & Included & Included & Included \\
\hline Industry fixed effect & Included & Included & Included & Included \\
\hline Area fixed effect & Included & Included & Included & Included \\
\hline Adj $R^{2}$ & 0.23 & 0.13 & 0.05 & 0.20 \\
\hline Obs & 7811 & 7811 & 7811 & 7811 \\
\hline
\end{tabular}

Firm performance is a dependent variable measured by ROA, Tobin's Q, stock returns and ROS. Pay dispersion is measured by either GAP or CPS. State is a dummy variable coded 1 if the firm has the government as the controlling shareholder and 0 otherwise. Reform is a dummy variable coded 1 for post reform period and 0 otherwise. Size is the log of a firm's total assets. Leverage is the ratio of total debts to total assets. Largest is the proportion of shares held by the largest shareholders. Board is the log of the total number of directors on the boards. Indep is the proportion of independent directors on the boards.

T-statistics are in parentheses, computed using the White (1980) heteroscedasticity robust standard error, clustered by firm.

$*, * *$ and $* * *$ indicate significance at the $10 \%, 5 \%$ and $1 \%$ levels, respectively.

\section{Robustness tests}

\subsection{Endogeneity}

Murphy (1999) and Firth et al. (2007) argue that it is effective to make managerial compensation a function of firm performance to solve the agency problems between managers and shareholders. Moreover, Palia (2001) suggests that managerial compensation and firm performance are jointly determined. Since pay dispersion is related to managerial compensation, we consider it to be endogenously determined. If this is the case, the OLS 
regression analysis will result in biased estimation results. To address the issue of endogeneity and examine whether our results are robust, we follow Kale et al. (2009) in applying a two-stage least square $(2 \mathrm{SLS})^{8}$. In the first stage we regress the CEO pay dispersion against a set of control variables and instrumental variables, as per the discussion in Kale et al. (2009) ${ }^{9}$. In the second stage we replace the CEO pay dispersion with the predicted value obtained from the first stage in our main regression. We report the results from the second stage in Table 7.

Table 7 presents the results from the second stage of Equation (2) using the 2SLS method of estimation. Panel A uses GAP as a measure of pay dispersion and Panel B uses CPS. We mainly focus on the coefficients of pay dispersion and the interaction terms between pay dispersion and the State dummy. The results of the regression show significantly positive coefficients on all pay-dispersion measurements (except the RET regression), and significantly negative coefficients on interaction terms across four specifications. The general results from Table 7 are broadly similar to those in Table 3. Again, these results indicate that pay dispersion is positively related to firm performance, and that this positive relationship is weaker in firms where the controlling shareholder is the state. We also apply the 2SLS to estimate all the other equations and get similar results to those reported in Table 3 to 6 . For the sake of brevity, we do not report these results in this paper.

Table 7. 2SLS estimation of pay dispersion on firm performance (second stage)

\begin{tabular}{lllll}
\hline \multicolumn{1}{l}{ Panel A: GAP is used as pay dispersion } & \multicolumn{1}{c}{ Q } & \multicolumn{1}{c}{ RET } & \multicolumn{1}{c}{ ROS } \\
\hline Dependent variable & \multicolumn{1}{c}{ ROA } & \multicolumn{1}{c}{ Q } & \multicolumn{1}{c}{ R } \\
Constant & $-0.19 * *(-2.01)$ & $4.86 * * *(3.15)$ & $-0.01(-0.07)$ & $-0.68 * * *(-4.33)$ \\
GAP & $0.09 * * *(2.85)$ & $0.12 * * *(8.12)$ & $0.22(0.07)$ & $0.15 * * *(7.25)$ \\
GAP*State & $-0.02 * * *(-2.62)$ & $-0.07 * *(-2.45)$ & $-0.02(-1.63)$ & $-0.03 * *(-2.49)$ \\
State & $0.09(1.62)$ & $0.02(0.56)$ & $0.02 *(1.72)$ & $0.02 * * *(3.72)$ \\
Size & $0.08 * * *(9.45)$ & $-0.17 * * *(-9.32)$ & $0.02 * * *(3.26)$ & $0.05 * *(2.15)$ \\
Leverage & $-0.12 * * *(-2.80)$ & $-0.91 * * *(-7.42)$ & $0.12 * * *(4.88)$ & $-0.32 * * *(-9.48)$ \\
Largest & $0.04 * * *(6.09)$ & $-0.75 * * *(-6.64)$ & $-0.02(-0.64)$ & $0.06 * * *(3.41)$ \\
Board & $0.02(0.67)$ & $-0.15 *(-1.64)$ & $-0.02(-0.91)$ & $0.02(0.47)$ \\
Indep & $-0.02(-1.42)$ & $1.08 * * *(3.20)$ & $-0.03(-0.04)$ & $-0.04(-0.89)$ \\
Year fixed effect & Included & Included & Included & Included
\end{tabular}

\footnotetext{
${ }^{8}$ As for selecting the instrumental variables, we follow Kale et al. (2009) and choose industry firm median pay dispersion. ${ }^{9}$ Other control variables include CEO tenure, CEO age, CEO duality, New CEO dummy, Insider CEO dummy, Retired CEO dummy, number of executives in the top management team, number of directors, ratio of independent directors to total number of directors, managerial ownership and volatility of stock returns. These variables are defined in Appendix A.1.
} 


\begin{tabular}{|c|c|c|c|c|}
\hline Industry fixed effect & Included & Included & Included & Included \\
\hline Area fixed effect & Included & Included & Included & Included \\
\hline Adj $R^{2}$ & 0.25 & 0.12 & 0.03 & 0.21 \\
\hline Obs & 7811 & 7811 & 7811 & 7811 \\
\hline \multicolumn{5}{|c|}{ Panel B: $C P S$ is used as firm performance } \\
\hline Dependent variable & ROA & Q & RET & ROS \\
\hline Constant & $-0.16 * * *(-8.14)$ & $5.36 * * *(4.77)$ & $-0.04(-0.32)$ & $-0.63 * * *(-9.55)$ \\
\hline CPS & $0.06 * *(2.30)$ & $0.10 * *(2.10)$ & $0.18(0.33)$ & $0.06 * * *(2.90)$ \\
\hline CPS*State & $-0.03 * * *(-2.88)$ & $-0.05 * *(-2.40)$ & $-0.02(-0.39)$ & $-0.02 * *(-2.21)$ \\
\hline State & $0.02(0.76)$ & $0.07 *(1.88)$ & $0.01(0.92)$ & $0.03 * * *(4.83)$ \\
\hline Size & $0.02 * * *(3.07)$ & $-0.15 * * *(-7.44)$ & $0.02 * *(2.11)$ & $0.04 * *(4.25)$ \\
\hline Leverage & $-0.14 * *(-2.25)$ & $-0.99 * * *(-8.04)$ & $0.15^{* * *}(5.81)$ & $-0.34 * * *(-3.02)$ \\
\hline Largest & $0.03 * * *(4.38)$ & $-0.85 * * *(-7.40)$ & $-0.02(-0.46)$ & $0.05 * *(2.46)$ \\
\hline Board & $0.03(0.72)$ & $-0.15(-1.56)$ & $-0.03(-1.20)$ & $0.01(0.45)$ \\
\hline Indep & $-0.02(-1.23)$ & $1.15 * * *(3.36)$ & $-0.03(-0.28)$ & $-0.03(-0.67)$ \\
\hline Year fixed effect & Included & Included & Included & Included \\
\hline Industry fixed effect & Included & Included & Included & Included \\
\hline Area fixed effect & Included & Included & Included & Included \\
\hline Adj $R^{2}$ & 0.22 & 0.10 & 0.02 & 0.20 \\
\hline Obs & 7811 & 7811 & 7811 & 7811 \\
\hline
\end{tabular}

Firm performance is a dependent variable measured by ROA, Tobin's Q, RET and ROS. Pay dispersion is measured by either GAP or CPS. State is a dummy variable coded 1 for state-controlled firms and 0 otherwise. Size is the log of firm's total assets. Leverage is the ratio of total debts to total assets. Largest is the proportion of shares held by the largest shareholders. Board is the log of the total number of directors on the boards. Indep is the proportion of independent directors on the boards.

T-statistics are in parentheses, computed using the White (1980) heteroscedasticity robust standard error, clustered by firms,

$*$, **and *** indicate significance at the $10 \%, 5 \%$, and $1 \%$ levels, respectively.

\subsection{Other robustness tests}

\subsubsection{Agency problems in family-controlled firms}

The first concern may be related to the application of tournament theory for those firms with agency issues between controlling and minority shareholders. Existing literature suggests that the divergence between the control rights and cash-flow rights of the controlling shareholders reflects the expropriation of minority shareholders (Claessens et al., 2002; Lemmon and Lin, 2003). Therefore, we create a new variable, Wedge, defined as the difference between the control rights and cash-flow rights of the controlling shareholders; this variable aims to capture the dominance of the agency problem between controlling and minority shareholders. Empirically, we rerun our Equation (2), replacing the State dummy with Wedge and using only the sub-sample of private firms. In the unreported results we find that the CEO pay dispersion is positively related to firm performance, and the coefficients of Wedge and the interaction terms between Wedge and CEO pay dispersion are both negative but insignificant. These results indicate that the tournament theory still applies without 
significant change in private firms when we control for the agency problem between controlling and minority shareholders. One possible explanation is that some of China's private firms are carved out from the former state-owned firms, and the ultimate controlling shareholders are usually several private entities. While the agency problem between the largest shareholders and other shareholders is not as severe as if the ultimate controller is an individual or a family, the agency problem between shareholders and managers still exists, since those private firms need to select managers to operate them. Therefore, the tournament incentive is generally still relevant in these private firms.

Now the question is whether tournament theory will also be relevant to family controlled firms where the CEO is also a member of the same family of shareholders, which would mitigate the agency problems between shareholders and managers. We expect that the owner CEO in family controlled firms will substitute for the tournament and reduce the effectiveness of tournament incentives. To test the effectiveness of tournament theory, we identify family controlled firms where CEO is the member of the family controlling shareholders, and create a new dummy variable Owner_CEO, which is equal to 1 for these firms. Empirically, we rerun our Equation (2) by replacing the State dummy with the Owner_CEO dummy, using only the sub-sample of private firms.

The results are reported in Table 8 . The regression results show that the coefficients on CEO pay dispersion are all positive and statistically significant (the only marginal significance relates to stock returns), indicating the application of tournament theory. The interaction terms between the CEO pay dispersion and Owner_CEO provide some interesting evidence. Across these specifications, the coefficients on the interaction terms are negative and significant, indicating that tournament incentives are weaker in firms where the CEO is also from the same family and is the ultimate controlling shareholder of the firm. These results suggest that in family-controlled firms where CEOs come from family shareholders, the owner-CEOs have more incentive to maximize firm value and less need to receive additional incentives through compensation from the firms; this is consistent with the prediction for the family-control incentive alignment hypothesis (McConaughy, 2000), and findings that family CEOs are unlikely to act against the interests of the company (Amoako- 
Adu et al., 2011).

Table 8. Tournament incentives and family-controlled firms

\begin{tabular}{|c|c|c|c|c|}
\hline \multicolumn{5}{|c|}{ Panel A:GAP is used as the CEO pay-dispersion measurement } \\
\hline Dependent variable & ROA & $\mathrm{Q}$ & RET & ROS \\
\hline GAP & $0.06 * * *(3.06)$ & $0.19 * * *(3.36)$ & $0.03(1.62)$ & $0.03 * * *(2.84)$ \\
\hline Owner_CEO & $-0.03(-1.26)$ & $0.72(1.08)$ & $1.03 * * *(3.31)$ & $-0.13 * * *(-2.62)$ \\
\hline GAP*Owner_CEO & $-0.01(-0.40)$ & $-0.06 * * *(-3.90)$ & $-0.06 * *(-2.34)$ & $-0.01 * *(-2.17)$ \\
\hline \multicolumn{5}{|c|}{$\begin{array}{l}\text { Other control variables include firm size, leverage, board size, independent directors, largest ownership, } \\
\text { year, industry and area fixed effects }\end{array}$} \\
\hline Adj R2 & 0.20 & 0.08 & 0.03 & 0.18 \\
\hline Obs & 3034 & 3034 & 3034 & 3034 \\
\hline \multicolumn{5}{|c|}{ Panel B: $C P S$ is used as the CEO pay-dispersion measurement } \\
\hline Dependent variable & $\mathrm{ROA}$ & $\mathrm{Q}$ & RET & ROS \\
\hline CPS & $0.02 * *(2.01)$ & $0.22 * *(2.49)$ & $0.27(1.32)$ & $0.05 * *(2.42)$ \\
\hline Owner_CEO & $-0.01(-1.48)$ & $0.18(1.41)$ & $0.42 * * *(5.96)$ & $-0.02 *(-1.84)$ \\
\hline CPS*Owner_CEO & $-0.03 * *(-2.45)$ & $-0.24 * * *(-3.53)$ & $-0.33(-1.55)$ & $-0.02 * *(-2.45)$ \\
\hline \multicolumn{5}{|c|}{$\begin{array}{l}\text { Other control variables include firm size, leverage, board size, independent directors, largest ownership, } \\
\text { year, industry and area fixed effects }\end{array}$} \\
\hline Adj R2 & 0.20 & 0.10 & 0.03 & 0.18 \\
\hline Obs & 3034 & 3034 & 3034 & 3034 \\
\hline
\end{tabular}

The dependent variable is firm performance, measured by $R O A$, Tobin's $\mathrm{Q}$, stock returns and ROS. Pay dispersion is measured by either GAP or CPS. Owner_CEO is a dummy variable equal to 1 for family controlled firms where the CEO is also the control family member. All the other variables are defined as in the previous tables.

T-statistics are in parentheses, computed using the White (1980) heteroscedasticity robust standard error, clustered by firm.

$*, * *$ and $* * *$ indicate significance at the $10 \%, 5 \%$ and $1 \%$ levels, respectively.

\subsubsection{Other components of CEO compensation}

The second concern may be related to the absence of stock options and perks in CEO compensation, as only cash components are used to calculate pay dispersion in this paper. The other major component of CEO compensation is long-term incentives such as stock options. In our previous empirical analysis we did not consider stock options when calculating CEO compensation: stock options are rarely granted in China's listed firms, and during our sample period there were fewer than 50 firms granting stock options to CEOs. However, due to data limitations it is impossible to calculate the values of stock options. Thus, we create the dummy variable Options, which is equal to 1 if stock options are granted for the specific firm-year observation. To see whether our results hold with the consideration of stock options, we rerun our Equation (2) by replacing the State dummy with the Options dummy using the full sample. The (unreported) results show that CEO pay dispersion is 
positively related to firm performance. Furthermore, the coefficients of the interaction terms between CEO pay dispersion and Options are positive and insignificant, indicating that excluding stock options will not change our main conclusions.

In addition, the literature also suggests that as part of CEO compensation, perks play an important role in providing incentives for executives in Chinese listed firms (Adithipyangkul et al., 2011). Following their work, we create the variable Perks, which equals the sum of the expenditures, including company cars, communications, socializing, meals, travel and entertainment, disclosed in the footnotes of firms' cash-flow statements in their annual reports. Since these expenditures are consumed by all top executives (not just CEOs) for both work and personal use, perks are not considered to be part of individual CEOs' compensation. However, our relevant question here is whether the effectiveness of tournament incentives is mitigated with the consumption of perks. We therefore rerun Equation (2) by replacing the State dummy with Perks. In the (unreported) results, we find that CEO pay dispersion continues to affect firm performance positively. More importantly, we find that perks relate to better firm performance but do not affect tournament incentives, as reflected by an insignificant coefficient on the interaction term between Perks and CEO pay dispersion. We further replicate our regression using the SOE sub-sample, obtaining similar results to those for the full sample. These results suggest that our findings associated with tournament incentives generally hold after considering other components of CEO compensation, including options and perks.

Some studies on China have argued that the Chairman is the highest-paid executive, and is also higher in status than the CEO (Firth et al., 2006b). They argue that the Chairman is the key person with the responsibility for making critical decisions. To take the situation of Chairman into account, we apply two alternative proxies for pay dispersion and repeat the analysis detailed above. These two alternative proxies are the difference between the Chairman's compensation and the median compensation of all the other executives, and the ratio of the Chairman's compensation to the total compensation of the top five executives. The general results are broadly similar to those reported from Table 2 to Table $8^{10}$.

\footnotetext{
${ }^{10}$ When the Chairman's compensation is applied, some control variables of CEO characteristics, such as CEO age, tenure and managerial ownership, are replaced with the Chairman's characteristics.
} 
We further check the robustness of the positive relationship between pay dispersion and firm performance by partitioning the entire sample on the basis of industry structure, firm size and ownership structure. Industry effects may be significant due to regulation and monopoly, although firms in high-technology industries usually set a higher pay dispersion to attract and retain their managers (Lee et al., 2008). To examine this we divide the total sample into high-technology and non-high-technology industries. The results across these two regressions are similar to those in Table 2.

Murphy (1999) suggests that a firm's operational complexity plays an important role in setting managerial compensation and pay dispersion. Since organizational complexity calls for high-quality managers, it is possible that in complicated firms, pay dispersion may lead to better firm performance. We proxy for firm complexity by firm size and divide our sample into quartiles. After examining the impact of pay dispersion on firm performance in the regression analysis, we find that the effect of pay dispersion is insignificant when firm size is in the lowest quartile. These results suggest that pay dispersion is more strongly associated with firm performance in larger firms.

We also test the robustness of our estimation results by using alternative measures of pay dispersion, including (1) the coefficient of variation in CEO and other executive compensation; (2) the ratio of CEO pay to the median of other executive compensation; and (3) the difference between CEO compensation and the second-highest executive compensation. Our results using these alternatives are qualitatively similar to the reported results. When we use the alternative measures of pay dispersion and firm performance to reestimate Equation (2), the result that pay dispersion is positively related to firm performance is robust. In particular, a negative and significant coefficient on the interaction term between State dummy and pay dispersion suggests that the positive relationship between pay dispersion and firm performance is weaker in SOEs. This relationship is also consistently observed when alternative measures are used in the 2SLS estimation. More importantly, the association between pay dispersion and stock returns becomes significant after the 'splitshare structure reform which is consistent with our hypothesis.

\section{Conclusion}


The issue relating to the pay gap between CEOs and other executives in the top management team has recently received a considerable amount of attention. An appropriate pay scheme is essential to the success of SOE reform. Information about executive compensation in China's listed firms has been disclosed since 1998, and more completely since 2005. We have taken advantage of this information to investigate pay dispersion and its effect on firm performance in China's listed firms using a sample ranging from 2005 to 2010.

Consistent with tournament theory and previous research (Kale et al., 2009; Chen et al., 2011a), we find that pay dispersion is positively related to firm performance. We also find that the positive association between pay dispersion and firm performance is weaker in SOEs than in privately controlled firms, because SOEs are required to achieve multiple economic and social goals such as the remittance of tax to governments and alternative incentive schemes. Moreover, the relationship between pay dispersion and firm performance is weakened by CEOs' political connections, and we find that this less-positive effect is significant in private firms. We specifically find that the positive relationship between CEO pay dispersion and firm performance has been strengthened since the split-share structure reform, but the positive effect of this reform is weaker in SOEs than in private firms. Furthermore, we also find that a significantly positive effect of CEO pay dispersion on stock returns emerged after the split-share structure reform. We provide evidence that state ownership and political connection exert a value-destroying effect by weakening the positive effect of tournament incentives, while market reform improves economic efficiency by strengthening tournament incentives. We argue that in SOEs the satisfaction gained from multiple economic and social goals, such as the remittance of tax imposed by governments, has largely reduced the effectiveness of tournament incentives; moreover, in familycontrolled firms where the CEO is also the family owner, the tournament theory does not hold at all. Overall, our results suggest that in an emerging market, a Chinese firm's institutional features, such as state ownership and political connections, play important roles in the effect of tournament incentives on motivating executives.

\section{Acknowledgement}


We acknowledge the valuable suggestions and comments on this paper by Professor JunKoo Kang, editor of the Pacific-Basin Finance Journal, and the anonymous referee, as well as comments by participants of the seminar organized by Department of Accounting, Finance and Economics, Griffith University, October 12, 2012.

Appendix A.1. Definitions of variables

\begin{tabular}{|c|c|}
\hline Variable & Definition \\
\hline \multicolumn{2}{|l|}{ Panel A: Managerial compensation } \\
\hline CEO compensation $(C P A Y)$ & Total cash compensation for CEO \\
\hline Top executive compensation (TPAY) & Total cash compensation for top five executives \\
\hline \multicolumn{2}{|l|}{ Panel B: Pay dispersion } \\
\hline GAP & $\begin{array}{l}\text { Log of difference between CEO pay and median of } \\
\text { other executive pay }\end{array}$ \\
\hline CEO pay slice $(C P S)$ & CPAY/TPAY \\
\hline \multicolumn{2}{|l|}{ Panel C: Firm performance } \\
\hline Return on assets $(R O A)$ & Net income/total assets \\
\hline Tobin’s Q & Market value/replacement value \\
\hline Stock returns $(R E T)$ & Firm annual stock return \\
\hline Return on sales $(R O S)$ & Net income/total sales \\
\hline \multicolumn{2}{|l|}{ Panel D: CEO characteristics } \\
\hline CEO age $(A g e)$ & Log of the age of the CEO \\
\hline CEO tenure (Tenure) & Log of the number of years as the firm's CEO \\
\hline CEO duality (Duality) & Equals 1 if CEO also chairs the board \\
\hline New CEO (New) & Equals 1 for first year as CEO \\
\hline Retiring CEO (Retire) & Equals 1 if CEO's age is more than 62 \\
\hline Inside CEO (Insider) & Equals 1 if CEO is promoted from inside \\
\hline Number of executives (Novp) & Log of the number of top executives \\
\hline \multicolumn{2}{|c|}{ Panel E: Firm characteristics and corporate governance } \\
\hline Firm size (Size) & Log of total assets \\
\hline Board size (Board) & Log of the number of directors on the board \\
\hline$\%$ Independent director (Pond) & Proportion of independent directors on the board \\
\hline Leverage (Lev) & Total debts/total assets in book value \\
\hline Investment opportunity (Invest) & Total assets growth ratio \\
\hline Largest shareholder (Largest) & Percentage of shares owned by the largest shareholder \\
\hline Managerial ownership (Mowner) & Percentage of shares owned by the CEO \\
\hline
\end{tabular}

\section{References}

Abowd, J., Kaplan, D., 1999. Executive compensation: six questions that need answering. Journal of Economic Perspectives 13, 145-167.

Adams, R. B., Almeida, H., Ferreira, D., 2005. Powerful CEOs and their impact on corporate 
performance. Review of Financial Studies 18(4), 1403-1432.

Adithipyangkul, P., Alon, I., Zhang, T., 2011. Executive perks: Compensation and corporate performance in China. Asia Pacific Journal of Management 28, 401-425.

Amoako-Adu, B., Baulkaran, V., Smith, B. F., 2011. Executive compensation in firms with concentrated control: The impact of dual class structure and family management. Journal of Corporate Finance 17, 1580-1594.

Aslan, H., Grinstein, Y., 2011. CEO compensation and political connectedness. SSRN working paper.

Bai, C., Li, D. D., Tao, Z., Wang, Y., 2000. A multitask theory of state enterprise reform. Journal of Comparative Economics 28(4), 716-738.

Bai, C., Lu, J., Tao, Z., 2006. The multitask theory of state enterprises reform: Empirical evidence from China. American Economic Review 96(2), 353-357.

Bebchuk, L. and Fried, J., 2003. Executive compensation as an agency problem. Journal of Economic Perspectives 17, 71-92.

Bebchuk, L. and Fried, J., 2004. Pay Without Performance: The Unfulfilled Promise of Executive Compensation. Harvard University Press, Cambridge, MA.

Bebchuk, L. A., Martijn, C., Urs, C. P., 2011. The CEO pay slice. Journal of Financial Economics 102(1), 199-221.

Bradshaw, M., Liao, G., Ma, M., 2012. State Ownership, Tax and Political Promotion: Evidence from China, SSRN working paper.

Burns, N., Minnick, K., Stacks, L. T., 2012. CEO Tournaments: A Cross-Country Analysis of Causes, Cultural Influences and Consequences. SSRN working paper.

Cao, J., Pan, X., Tian, G., 2011a. Disproportional ownership structure and pay-performance relationship: Evidence from China's listed firms. Journal of Corporate Finance 17(3), 541554.

Cao, J., Lemmon, M., Pan, X., Tian, G., Qian, M., 2011b. Political Promotion, CEO Incentives, and the Relationship between Pay and Performance. Working paper.

Cao, J., Lemmon, M., Pan, X., Tian, G., Qian, M., 2012. Political Capital or Constraint: Evidence from Entrenchment of Politically Connected CEOs. Working paper. 
Chang, E. C., Wong, S. M. L., 2009. Governance with multiple objectives: Evidence from top executive turnover in China. Journal of Corporate Finance 15, 230-244.

Chen, G., Firth, M., Xu, L., 2009. Does the type of ownership control matter? Evidence from China's listed companies. Journal of Banking and Finance 33, 171-181.

Chen, D., Li, Z., Liang, S., 2010. Do Managers Perform for Perks? Working paper.

Chen, J., Ezzamel, M., Cai, Z., 2011a. Managerial power theory, tournament theory, and executive pay in China. Journal of Corporate Finance 17(4), 1176-1199.

Chen, J.P., Li, Z., Su, X., Sun, Z., 2011b. Rent seeking incentives, corporate political connections and the control structure of private firms: Chinese evidence. Journal of Corporate Finance 17(2), 229-243.

Claessens, S., Djankov, S., Fan, J. P. H., Lang, L.H.P., 2002. Disentangling the incentive and entrenchment effects of large shareholdings. Journal of Finance 57, 2741-2771.

Clarke, D. C., 2003. Corporate governance in China: An overview. China Economic Review $14,494-507$

Conyon, M.J., Murphy, K.J., 2000. The prince and the pauper? CEO pay in the United States and United Kingdom. The Economic Journal 110, 640-671.

Conyon, M. J., Peck, S., Sadler, G., 2001. Corporate tournaments and executive compensation: evidence from the U.K. Strategic Management Journal 22(8), 805-815.

Conyon, M., Judge, W. Q., Useem, M., 2011. Corporate governance and the 2008-09 financial crisis. Corporate Governance: An International Review 19(5), 399-404.

Core, J. E., Holthausen. R. W., Larcker, D. F., 1999. Corporate governance, chief executive officer compensation, and firm performance. Journal of Financial Economics 51(3), 371-406. Core, J. E., Guay, W. R., 2010. Is There a Case for Regulating Executive Pay in the Financial Services Industry? SSRN working paper.

Eriksson, T., 1999. Executive compensation and tournament theory: Empirical tests on Danish Data. Journal of Labor Economics 17(2), 262-280.

Faccio, M., 2006. Politically connected firms. American Economic Review 96(1), 369-386

Faccio, M., Masulis, R. W., McConnell, J. J., 2006. Political connections and corporate bailouts. Journal of Finance 61(6), 2597-2635. 
Fahlenbrach, R., Stulz, R. M., 2011. Bank CEO incentives and the credit crisis. Journal of Financial Economics 99(1), 11-26.

Fan, J. P. H., Wong, T. J., Zhang, T. Y., 2007. Politically connected CEOs, corporate governance, and post-IPO performance of China's newly partially privatized firms. Journal of Financial Economics 84(2), 330-357.

Firth, M., Fung, P. M. Y., Rui, O. M., 2006a. Corporate performance and CEO compensation in China. Journal of Corporate Finance 12(4), 693-714.

Firth, M., Fung, P. M. Y., Rui, O. M., 2006b. Firm performance, governance structure and top management turnover in a transitional economy. Journal of Management Studies 43(6), $1289-1330$.

Firth, M., Fung, P. M. Y., Rui, O. M., 2007. How ownership and corporate governance influence chief executive pay in China's listed firms. Journal of Business Research 60, 776785.

Firth, M., Leung, T. Y., Rui, O. M., 2010, Justifying top management pay in a transitional economy. Journal of Empirical Finance 17 (5), 852-866.

Gabaix, X. Landier, A., 2008. Why has CEO pay increased so much? Quarterly Journal of Economics 123, 49-100.

Garner, J., Kim, W., 2010. Does a Salary Cap Really Work? What the US can learn from Korean evidence. SSRN working paper.

Groves, T., Hong, Y., Mcmillan, J., Naughton, B., 1994. Autonomy and incentives in Chinese state enterprises. The Quarterly Journal of Economics 109(1), 183-209.

Hubbard, R., Palia, D., 1995. Executive Pay and Performance: Evidence from the U.S. Banking Industry. Journal of Financial Economics 39, 105-130.

Jensen, M., 2001. Value maximization, stakeholder theory, and the corporate objective function. European Financial Management Review 7(3), 297-317.

Jensen, M. C., Murphy, K. J., 1990. Performance pay and top-management incentives. Journal of Political Economy 98(2), 225-264.

Kale, J. R., Reis, E., Venkateswaran, A., 2009. Rank-order tournaments and incentive alignment: the effect on firm performance. Journal of Finance 64 (3), 1479-1512. 
Kaplan, S., 1994. Top executive rewards and firm performance: A comparison of Japan and the U.S. Journal of Political Economy 102, 510-546.

Kato, T., Long, C. 2005. Executive Compensation, Firm Performance, and Corporate Governance in China: Evidence from Firms Listed in the Shanghai and Shenzhen Stock Exchanges, IZA working paper.

Lambert, R. A., Larcker, D. F., Weigelt, K., 1993. The structure of organizational incentives. Administrative Science Quarterly 38(3), 438-461.

Landier, A., David, S., David, T., 2008. Bottom-up Corporate Governance. New York University. Working paper.

Lazear, E. P., Rosen, S., 1981. Rank-order tournaments as optimum labor contracts. Journal of Political Economy 89, 841-864.

La Porta, R., Lopez-de-Silanes, F., Shleifer, A., Vishny, R.W., 1998. Law and finance. Journal of Political Economy 106, 1113-1154.

La Porta, R., Lopez-de-Silanes, F., Shleifer, A., Vishny, R.W., 2002. Investor protection and corporate valuation. The Journal of Finance 57 (3), 1147-1170.

Lemmon, M., Lins, K. V., 2003. Ownership structure, corporate governance, and firm value: Evidence from the East Asian financial crisis. The Journal of Finance 4, 1445-1468.

Li, K., Wang, T., Cheung, Y., Jiang, P., 2011. Privatization and risk sharing: Evidence from the split share structure reform in China. Review of Financial Studies 24(7), 2499-2525.

Lee, K. W., Lev, B., Yeo, G. H. H., 2008. Executive pay dispersion, corporate governance, and firm performance. Review of Quantitative of Finance and Accounting 30(3), 315-338.

Li, H. B., Meng, L. S., Wang, Q., Zhou, L. A., 2008. Political connections, financing and firm performance: Evidence from Chinese private firms. Journal of Development Economics 87(2), 283-299.

Lin, B., Lu, R., 2009. Managerial power, compensation gap and firm performance-Evidence from Chinese public listed companies. Global Finance Journal 20, 153-164.

Main, B. G. M., O’Reilly, C. A., Wade, J., 1993. Top executive pay: Tournament or teamwork? Journal of Labor Economics 11(4), 606-628.

McConaughy, D., 2000. Family CEOs vs. Nonfamily CEOs in family-controlled firms: An 
examination of the level and sensitivity of pay to performance. Family Business Review 13, 121-131.

Murphy, K. J., 1999. Executive compensation. Handbook of Labour Economics.

O’Reilly, C. A., Main, B. G., Crystal, G. S., 1988. CEO compensation as tournament and social comparison: A tale of two theories. Administrative Science Quarterly 33(2), 257-274.

Palia, D., 2001. The Endogeneity of Managerial Compensation in Firm Valuation: A Solution. Review of Financial Studies 14(3), 735-764.

Rajgopal, S., Srinivasan, S., 2006. Pay dispersion in the executive suite. Working paper.

Shirley, M. and Xu, L., 2001. The Empirical Effects of Performance Contracts. Journal of Law, Economics and Organization 17, 168-200.

Shleifer, A., Vishny, R. W., 1997. A survey of corporate governance. Journal of Finance $52(2), 737-783$.

Sun, Q., Tong, W. H. S., 2003. China share issue privatization: the extent of its success. Journal of Financial Economics 70, 183-222.

Wei, Z., Varela, O., D’Souza, J., Hassan, M. K., 2003. The financial and operating performance of China's newly privatized firms. Financial Management 32(2), 107-126.

White, H., 1980. A heteroskedasticity-consistent covariance matrix estimator and a direct test for heteroskedasticity. Econometrica 48 (4), 817-838.

Yermack, D., 1996. Higher market valuation of companies with a small board of directors. Journal of Financial Economics 40(2), 185-211.

Yueh, L. Y., 2004. Wage reforms in China during the 1990s. Asian Economic Journal 18(2), 149-164. 